\title{
Tissue Harvesting for Adoptive Tumor Infiltrating Lymphocyte Therapy in Metastatic Melanoma
}

\author{
DOUGLAS ZIPPEL ${ }^{1,2,3}$, ORLI FRIEDMAN-ELDAR ${ }^{1,2,3}$, SHLOMI RAYMAN ${ }^{1}$, \\ DAVID HAZZAN ${ }^{1,3}$, AVIRAM NISSAN $^{1,3}$, GAL SCHTRECHMAN ${ }^{1}$, GAL MARKEL $^{2,4,5}$, \\ JACOB SCHACHTER $^{2,4,5}$, ORIT ITZHAKI ${ }^{2,5}$ and MICHAL J. BESSER ${ }^{2,5}$ \\ ${ }^{1}$ Department of Surgery C \& Surgical Oncology, Chaim Sheba Medical Center, Ramat Gan, Israel; \\ ${ }^{2}$ Ella Lemelbaum Institute for Immuno Oncology, Chaim Sheba Medical Center, Ramat Gan, Israel; \\ ${ }^{3}$ Department of Surgery, Sackler School of Medicine, Tel Aviv University, Tel Aviv, Israel; \\ ${ }^{4}$ Department of Oncology, Chaim Sheba Medical Center, Ramat Gan, Israel; \\ ${ }^{5}$ Department of Clinical Microbiology and Immunology, \\ Sackler School of Medicine, Tel Aviv University, Tel Aviv, Israel
}

\begin{abstract}
Background/Aim: Adoptive transfer of tumorinfiltrating lymphocytes (TILs) combined with nonmyeloablative chemotherapy (NMA) has been shown to prolong survival in patients with metastatic disease. Materials and Methods: Tissue harvesting was performed form a variety of sites. TILs were isolated, expanded and infused with bolus high-dose IL-2. Results: Between 2008 and 2018, 242 lesions were resected for TILs harvesting from a range of sites form 196 patients without mortality and with minimal morbidity. Of those harvested, 75 were unable to complete therapy because of clinical deterioration during the wait period. Of 121 evaluable treated patients, there was no effect of metastatic site biopsied on the mean fold TIL expansion. Those receiving prior ipilimumab had a higher TIL fold expansion but a lower TIL fold expansion than those exposed to anti-PDI therapy. Conclusion: Harvesting may be safely performed with successful TIL expansion from most sites. Prior check point inhibitory immunotherapy may potentially influence TIL fold expansion.
\end{abstract}

Until recently, metastatic melanoma had a poor prognosis with an average survival $<1$ year (1). There have been a range of recent developments in immunotherapy that offer new promise which include monoclonal antibody therapies directed toward checkpoint inhibitory molecules (e.g. anti-CTLA-4 ipilmumab) and anti-PD-1 antibodies, (pembrolizumab,

Correspondence to: Douglas Zippel, MD, Department of Surgery C, Chaim Sheba Medical Center, Tel Hashomer, Ramat Gan 52621, Israel. Tel: +972 35302714, e-mail: dov.zippel@sheba.health.gov.il

Key Words: Adoptive cell therapy, metastatic melanoma, tumorinfiltrating lymphocyte therapy, ipilimumab, PD-1 antibody therapy. nivolumab). Both of these treatments are designed to interrupt signal pathways which inhibit antigen-restricted $\mathrm{T}$ cell activation $(2,3)$. Another approach uses a variety of adoptive $\mathrm{T}$ cell (ACT) treatments, which take advantage of the endogenously elicited immune response $(4,5)$. By comparison with older conventional therapies such as interleukin-2 (IL-2) and dacarbazine (DTIC) where objective tumor regression was possible in only $15-20 \%$ of patients (6), ACT has consistently shown high response rates with reported long-term sustained remissions and survival (7-9) that may be comparable to PD1-based blockade (2). ACT has consistently shown high response rates with reported long-term sustained remissions and survival (7-9) in metastatic melanoma that may be comparable to PD-1-based blockade (2). In addition, ACT has shown promise in other malignancies as well (10-12). Adoptive transfer of autologous ex vivo-expanded tumorinfiltrating lymphocytes (TILs), originally pioneered by Rosenberg and colleagues, has specific advantages capitalizing on the proliferation of polyclonal populations of $\mathrm{T}$ cell tumor infiltrates capable of recognizing multiple shared melanoma tumor-associated antigens (TAAs) and mutation-derived neoantigens $(5,8,13)$. An enhanced ACT success has been achieved by patient pre-conditioning using non-myeloablative chemotherapy (NMA) with cyclophosphamide and fludarabine with or without the addition of total body irradiation (TBI) following which there is an infusion of large numbers of autologous TILs (14). The TIL-ACT approach is supplemented with high-dose bolus IL-2 designed to prolong adoptive TIL survival with this combined therapeutic regimen showing a $50 \%$ response rate in metastatic melanoma patients (15-17). In this respect, Rosenberg and colleagues have shown increased long-term response when compared with historical controls treated with conventional pre-immunotherapy era therapies (8). We previously reported a $40 \%$ objective 
response rate in 57 patients with a 15.2 month median survival, (9) comparable to published response rates ranging between $40-60 \%$ which have been reported from the few centers worldwide that are using a combined lymphodepletion, ACT and high-dose IL-2 protocol $(15,18,19)$.

There are a number of novel therapeutic ACT strategies under development, based on the isolation and cultivation of TAA-specific T cells derived from melanomas. These cells can be obtained from peripheral blood mononuclear cells (PBMC) or from $\mathrm{T}$ cells transduced ex vivo either with TAA-reactive Tcell receptor (TCR) genes or chimeric antigen receptors (CARs) specific for melanoma cell surface antigens $(14,20,21)$. As all patients require fresh tumor tissue for the harvesting of TILs which then need to be cultured and expanded, the choice of the most appropriate metastatic site (or sites) where a harvest can be safely performed should be personalized for each patient. Our group has previously shown that certain tumor sites may generate TILs more successfully than others (22), where TILs with an increased in vitro anti-tumor reactivity have been derived from lung lesions as opposed to non-lung metastatic sites. These types of considerations must be weighed, however, against the morbidity and complexity of the surgery involved and the impact of a range of anti-melanoma pre-treatments which could potentially affect successful TIL culture and growth. We provide an update of our ongoing program from the Ella Lemelbaum Institute of Immuno Oncology at the Chaim Sheba Medical Center, Israel presenting surgical considerations relevant to TIL harvesting in ACT-eligible patients.

\section{Patients and Methods}

Patients. Permission was provided by the Institutional Review Board for the conduct and analysis of the data, which are maintained in a dedicated prospective database. Participating patients signed an informed consent which had been approved by the Israeli Ministry of Health (approval No. 3518/2004) in accordance with the conduct of a prior registered clinical trial NCT 00287131 (clinicaltrials.gov). The Ella Lemelbaum Institute for Immuno Oncology, within the Chaim Sheba Medical Center, is the principal tertiary referral center for melanoma and immunotherapy treatment in Israel. Inclusion criteria permitted analysis of stage IV melanoma patients with an ECOG performance status of 0-2, measurable disease and a life expectancy of at least 3 months. Exclusion criteria were: age of patients $<18$ years, HIVpositivity and Hepatitis B and/or C-positivity.

Tissue resection and TILs harvesting. Patients underwent tissue harvesting prior to initiating the ACT protocol with the production of young TILs as has been previously described $(9,23)$. In brief, preliminary surgical consultation was made for determining the most appropriate site for tumor excision and TIL harvesting. This decision was based upon tumor mass, size, location, Positron emission tomography (PET) avidity (as a qualitative measure of cellular infiltrate) and ease of access. Following harvest, after a combined collagenase and DNase digestion of the tumor (either for 2-3 $\mathrm{h}$ at $37^{\circ} \mathrm{C}$ or overnight at room temperature) the tissue was broken up into 1-3 $\mathrm{mm}^{3}$ fragments and then transferred to 24-well plates. Cells were cultured in medium with $3,000 \mathrm{IU} / \mathrm{ml} \mathrm{rhIL}-2$ (Proleukin, Chiron B.V.) for 2 to 4 weeks. A cut-off for established cultures was defined as $80 \times 10^{6} \mathrm{~T}$ cells. Unselected TIL cultures were further expanded ex vivo to treatment levels in a 14-day rapid expansion procedure (REP) using anti-CD3 antibody (Orthoclone OKT3, Janssen-Cilag: Johnson and Johnson, New Brunswick,NJ USA 3,000 IU/mL rhIL-2 and irradiated feeder cells as previously described $(24,25)$. On the day of infusion, reduction of the culture medium volume was performed using a COBE Spectra apheresis machine (COBE Laboratories Inc. Lakewood, CO, USA) (26).

Prior to NMA conditioning, granulocyte colony-stimulating factor (GCSF)-mobilized stem cells were obtained with leukapheresis as a safety net for those cases unable to reconstitute their hematopoietic system.

Patient treatments. Up until January 1st 2018, patients received an NMA conditioning regimen of cyclophosphamide $(60 \mathrm{mg} / \mathrm{kg}$ for 2 days) plus fludarabine $\left(25 \mathrm{mg} / \mathrm{m}^{2}\right.$ for 5 days) prior to cell infusion. Because of 3 mortalities potentially attributable to cyclophosphamide-induced cardiomyopathy, this NMA protocol was changed to fludarabine $\left(25 \mathrm{mg} / \mathrm{m}^{2}\right.$ for 3 days $)$ and Total Body Irradiation (TBI) (200 cGy for one day). Young TILs were administered intravenously followed by bolus high-dose IL-2 (720,000 IU/kg) every $8 \mathrm{~h}$ to tolerance (with a maximum of 15 doses). Following TIL infusion, patients commenced preventative therapy with GCSF (10 $\mathrm{mg} / \mathrm{kg}$ daily) plus fluconazole and acyclovir until the absolute neutrophil count reached $1,000 / \mu 1$. Platelets were transfused when the platelet count was $<20,000 / \mu l$. Patients also received sulphamethoxazole /trimethoprim twice weekly for at least 6 months (where possible) until the CD4 counts reached 200/ $\mu$ l.

Statistical analysis. Clinical data were analyzed as part of the ongoing prospective clinical trial. Data were entered and analyzed in SPSS version 23.0. (Version 23.0; SPSS Inc., Chicago, IL, USA). Descriptive statistics were produced using frequencies $(\mathrm{N}, \%)$ for categorical variables (e.g. gender) and means and standard deviations or medians and ranges for continuous variables (e.g. age). The cohort was divided by source of tissue harvest in order to explore the fold expansion means differences using the one-way ANOVA test. To predict primary outcome (High fold expansion), multivariate analysis (logistic regression) was conducted to obtain Odds-Ratios (OR) with $95 \%$ confidence intervals (CI). $p$-Values $<0.05$ were considered significant.

\section{Results}

Between 2008 and 2018, 242 lesions were surgically resected for TIL harvesting from 196 patients eligible for the ACT protocol. This cohort included some patients who underwent tissue harvest from more than one source. There were 75 females and 121 males (overall median age 53 years, range $=18-70$ years). The most common sources of harvested tumor tissue were subcutaneous nodules $(93 / 242$; $38.43 \%)$, lymph nodes $(58 / 242 ; 24 \%)$, lung nodule excisions $(47 / 242 ; 19.42 \%)$, and other sites, which included visceral organs such as the liver, spleen, gall bladder, adrenal, small bowel and colon, $(32 / 242 ; 13.22 \%)$. There were other miscellaneous sites $(12 / 242 ; 5 \%)$ which included the CNS, 
Table I. List of sites for TIL harvesting ( $n=242)$.

\begin{tabular}{lc}
\hline Tissue source & Number $(\%)$ \\
\hline Subcutaneous & $93(38.4)$ \\
Lymph node & $58(24)$ \\
Lung & $47(19.4)$ \\
Visceral & $32(13.2)$ \\
CNS & $5(2.1)$ \\
Muscle & $4(1.7)$ \\
Bone & $2(0.8)$ \\
Breast & $1(0.4)$ \\
\hline
\end{tabular}

muscle, bone and breast tissue (Table I). Of these 242 operations, $162(66.9 \%)$ were performed under general anesthesia and $80(33.1 \%)$ under local anesthesia.

Mortality with severe surgical morbidity (defined as any complication that resulted in delay in initiation of the NMA lymphodepletion protocol) was limited to three cases. In one, there was a complete dehiscence of the laparotomy wound with evisceration which required urgent reoperation and repair. In another case, there was a persistent pancreatic leak following splenectomy which required long term drainage. The third case presented with persistent pleural effusion which required ongoing thoracocentesis.

There were 75 patients (38.2\%) who underwent harvesting surgery but who did not complete the treatment plan. The majority of them had clinical deterioration before TILs could be infused. Within this group, there were 3 chemotherapyrelated deaths (all of which were cyclophosphamide-induced cardiomyopathy) as well as those patients whose TIL cultures could not be generated successfully. Overall, 105 patients were able to undergo the complete treatment protocol with infusion of both autologous TILs and rhIL-2 following NMA lymphodepletion. Another 16 patients are currently awaiting treatment resulting in a total of 121 patients whose TILs will be successfully cultured and expanded ready for infusion. The mean fold expansion after REP was $1,083 \pm 499$ (median 1,062, range $=207-2667$ ). After excluding groups such as the CNS and others with small sample sizes, one-way ANOVA with post-hoc testing showed no significant difference in the average fold expansion between the main sites $(\mathrm{F}(3.99)=0.559, p=0.64)$.

Groups were separated according to the median fold expansion value $(\leq$ or $>1062)$ and the median age $(\leq$ or $>53$ years) and the impact of gender, BRAF mutation status, prior treatment with BRAF inhibitors and previous treatment with ipilimumab, pembrolizumab or nivolumab on predictably larger TIL fold expansion was analyzed by logistic regression (Table II). Although overall no statistically significant differences were noted which might predict for a greater or lesser TIL fold expansion $(p=0.32)$, patients who
Table II. Multivariate analysis comparing the predicted TIL fold expansion according to age, gender, BRAF mutation status or prior treatment with the anti CTLA-4 antibody ipilimumab or anti-PD1 antibody therapy (pembrolizumab/nivolumab). Data are shown as Odds Ratios $(O R)+95 \%$ Confidence Intervals $(C I)$.

\begin{tabular}{lccc}
\hline Parameter & OR & $p$-Value & $95 \% \mathrm{CI}$ \\
\hline Age (>53 years) & 0.646 & 0.343 & $0.261,1.594$ \\
Female gender & 0.447 & 0.092 & $0.1751,0.142$ \\
BRAF mutation (positive) & 1.018 & 0.976 & $0.325,3.191$ \\
Prior BRAF inhibitor therapy & 1.000 & 1.000 & $0.259,3.866$ \\
Prior ipilimumab therapy & 2.850 & 0.083 & $0.871,9.329$ \\
Prior anti-PD1 antibody therapy & 0.529 & 0.311 & $0.154,1.813$ \\
\hline
\end{tabular}

Multivariate regression: $\mathrm{R}^{2}=0.01, \chi^{2}(6)=7.02, p=0.32$.

had received ipilimumab therapy prior to tissue harvesting were more likely to show a higher fold TIL expansion $(\mathrm{OR}=2.85,95 \% \mathrm{CI}=0.87-9.33 ; p=0.083)$ whereas prior anti PD-1 treatment had a negative impact on TIL fold expansion $(\mathrm{OR}=0.53,95 \% \mathrm{CI}=0.15-1.81 ; p=0.3)$. Older age and female gender were also associated with a lower TIL fold expansion although without significance.

\section{Discussion}

In this study, of 242 lesions resected from a range of sites for TIL harvesting for the purpose of treating patients with metastatic melanoma, no differences were noted in TIL expansion between the sites of biopsy. A higher fold TIL expansion was, however, found in those cases previously receiving the anti-CTLA-4 antibody ipilimumab whereas less TIL fold expansion was observed in patients previously treated with anti-PD-1 monoclonal antibody therapy (pembrolizumab or nivolumab).

Tumor-infiltrating lymphocyte (TIL) therapy has both theoretical and practical advantages in the management of stage IV melanoma. Large populations of TILs can be selected in vitro for the adoptive transfer of cells (ACT) which are designed to overcome tumor tolerance. This approach is combined with a pretreatment regimen of lymphodepletion capable of modifying the host and stimulating an optimal antitumor microenvironment by potentially eliminating immunoregulatory (Treg) cells and myeloid-derived suppressor cells (27) as well as by reducing the competition for cytokines normally promoting lymphocyte growth (28). It has been suggested that there is a better anti-tumor responsiveness when, after infusion, there are persistent TILs with multiple tumor-reactive T cell clonotypes detectable both in the peripheral blood and within tumor deposits $(29,30)$.

Although our group has previously shown that lung-derived TILs tend to have a higher rate of culture success where larger cell numbers with an enhanced anti-tumor reactivity are 
generated (22), the present analysis indicates that tissue source per se is not a guarantee of a larger fold expansion of TILs. Although the lungs comprise between $15-35 \%$ of melanoma metastases, viable TILs have been able to grow from the majority of patients and from most sites of resection (31). Therefore, in contrast to the previous study, the data in this study suggest that biopsy site is less important in fold expansion of harvested TILs and the selection by prior immunotherapy of likely immuno-stimulatory TIL subpopulations is noteworthy. As in our case, however, there will be patients who undergo TIL harvesting but are not treated largely because of clinical deterioration, a status which has partly been obviated by the use of TILs with a shorter growth cycle, termed "young TILs" $(7,25,32,33)$. In this setting, as the NMA commences 7 days before TIL infusion, patients selected for therapy should be fit enough to undergo treatment about 3 weeks post-surgery and the predicted risk of surgical complications associated with larger biopsy procedures should be deemed minimal. Specifically, the morbidity of any proposed procedure needs to account for the patient being fit for treatment in a timely fashion. Our cohort included 3 patients whose treatment was delayed because of their postsurgical morbidity, which can have important oncological consequences. The typical patient chosen for ACT has already progressed through a range of conventional therapies. The surgeon's role is critical in patients with a limited life span or with extensive tumor burden so that the patient is correctly selected for ACT as is the surgical approach likely to result in a high TIL yield with minimal morbidity. There is also the option of cryopreservation of cells for delayed treatment. In general, although tumor size does not correlate with TIL efficacy, lesions generally $>2 \mathrm{~cm}$ in diameter should be chosen so as to ensure adequate tissue processing, avoiding those tumors with potentially necrotic or infective elements (34).

There was an enhanced TIL expansion in patients who received ipilimumab and conversely a reduced TIL expansion if there was prior anti-PD-1 therapy. Anti-tumor $\mathrm{T}$ cell responses are regulated via a complicated balance of inhibitory and activating signals by which some tumors escape immune surveillance. Checkpoint inhibitory molecules are designed to rescue exhausted anti-tumor T cell populations and restore TCR activation through different, but complementary mechanisms (35). The anti-CTLA-4 monoclonal antibody ipilimumab inhibits the interaction of CD80/86 on antigen presenting cells with CTLA- 4 on T cells via $\mathrm{CD} 28$, blocking the inhibition of $\mathrm{T}$ cell co-stimulation and reversing an expected suppression of $\mathrm{T}$ cell activation (36). Ipilimumab, which has shown an improvement in overall survival of patients with metastatic melanoma in two phase III randomized controlled trials $(37,38)$ enhances antitumor activity and TIL persistence and maintains a broad repertoire of TCR specificities lowering the threshold for TCR activation and permitting clonal expansion (39).
By contrast, PD-1 inhibitors are implicated in reverting peripheral tolerance by blocking the binding of PD-1 ligands (PD-L1 and PD-L2) and restoring the immune capacity of T cells in the periphery which have been previously chronically activated. Both pembrolizumab and nivolumab also affect the suppressive function of Tregs and other dampening effector $\mathrm{T}$ cells, normally present in ongoing sites of inflammation within tumors, which utilize the PD-1 axis as a shield from immunemediated destruction. The effects of anti-PD-1 therapy on the signaling of B cells and antigen presenting cells will also result in $\mathrm{T}$ cell-independent immune stimulation (40). The association, however, between the inflammatory tumor infiltrate and the use of checkpoint inhibitory immunotherapy is complicated since infused TILs can trigger their own inhibition by secreting cytokines which drive the PD- 1 axis and its production of inhibitory ligands. Some of these paradoxical effects allow TILs to actually thwart their immunostimulatory impact by producing inflammatory cytokines which can induce tumor-derived PD-1 expression and secondarily promote $\mathrm{T}$ cell apoptosis $(41,42)$.

The nature of the immune tumor microenvironment affects melanoma survival and may precede anti-PD-1 therapy (43). Despite there being an association between the outcome in advanced melanoma and the degree of inflammatory infiltrate into the tumor (44), geographic localization of infiltrate with PD-L1 expression at the edge of tumor can cause adaptive immune resistance. This is likely in response to prior immunotherapeutic treatments (45).

In this context, the positive correlation between the presence of an inflamed tumor microenvironment and the response to agents such as ipilimumab would imply that prior immunotherapies can protect or potentiate ongoing rather than de novo anti-tumor immunity (46). For different melanomas, the persistence of TILs is important in the antitumor response, however, this may also reflect a selective feedback mechanism of immune resistance during immunotherapy which is induced by the tumor infiltrate itself. The nature of this interaction between TILs, the induced cytokine profile and the local checkpoint inhibitory ligand expression needs further assessment along with the correlation between these parameters and the composition of the infiltrate, the persistence of inflammation and the type of immunotherapy used.

\section{Conflicts of Interest}

The Authors have no conflicts of interest to declare regarding this study.

\section{Authors' Contributions}

Study Concept and Design: DZ, JS MJB; Data Acquisition: OFE, SR, DH, GS; Statistical Analysis: GS; Data Analysis and 
Interpretation: DZ, GM, OI, MJB; Manuscript preparation: DZ; Manuscript editing and review: DZ, GM, AN, MJB.

\section{Acknowledgements}

The Authors would like to thank Professor Andrew Zbar for his editorial assistance in the preparation of this manuscript.

\section{References}

1 Tarhini AA and Agarwala SS: Cutaneous melanoma: available therapy for metastatic disease. Dermat Ther 19(1): 19-25, 2006. PMID: 16405566. DOI: 10.1111/j.1529-8019.2005.00052.x

2 Weiss SA, Wolchok JD and Sznol M: Immunotherapy of melanoma: facts and hopes. Clin Cancer Res, 2019. PMID: 30923036. DOI: 10.1158/1078-0432.CCR-18-1550

3 Tang T, Eldabaje R and Yang L: Current Status of Biological Therapies for the Treatment of Metastatic Melanoma. Anticancer Res 36(7): 3229-3241, 2016. PMID: 27354579.

4 Locher C, Conforti R, Aymeric L, Ma Y, Yamazaki T, Rusakiewicz S, Tesnière A, Ghiringhelli F, Apetoh L, Morel Y, Girard JP, Kroemer G and Zitvogel L: Desirable cell death during anticancer chemotherapy. Ann NY Acad Sci 1209: 99108, 2010. PMID: 20958322. DOI: 10.1111/j.1749-6632.2010. 05763.x

5 Yang JC and Rosenberg SA: Adoptive T-cell therapy for cancer. Adv Immunol 130: 279-294, 2016. PMID: 26923004. DOI: 10.1016/bs.ai.2015.12.006

6 Atkins MB, Kunkel L, Sznol M and Rosenberg SA: High-dose recombinant interleukin-2 therapy in patients with metastatic melanoma: long-term survival update. Cancer J Sci Am 2000(Suppl 1): S11-S14. PMID: 10685652

7 Besser MJ, Shapira-Frommer R, Treves AJ, Zippel D, Itzhaki O, Hershkovitz L, Levy D, Kubi A, Hovav E, Chermoshniuk N, Shalmon B, Hardan I, Catane R, Markel G, Apter S, Ben-Nun A, Kuchuk I, Shimoni A, Nagler A and Schachter J: Clinical responses in a phase II study using adoptive transfer of shortterm cultured tumor infiltration lymphocytes in metastatic melanoma patients. Clin Cancer Res 16(9): 2646-2655, 2010. PMID: 20406835. DOI: 10.1158/1078-0432.CCR-10-0041

8 Rosenberg SA, Yang JC, Sherry RM, Kammula US, Hughes MS, Phan GQ, Citrin DE, Restifo NP, Robbins PF, Wunderlich JR, Morton KE, Laurencot CM, Steinberg SM, White DE and Dudley ME: Durable complete responses in heavily pretreated patients with metastatic melanoma using T-cell transfer immunotherapy. Clin Cancer Res 17(13): 4550-4557, 2011. PMID: 21498393. DOI: 10.1158/1078-0432.CCR-11-0116

9 Besser MJ, Shapira-Frommer R, Itzhaki O, Treves AJ, Zippel DB, Levy D, Kuby A, Shoshani N, Zikich D, Ohayon Y, Ohayon D, Shalmon B, Markel G, Yerushalmi R, Apter S, Ben-Nun A, Ben-Ami E, Shimoni A, Nagler A and Schachter J: Adoptive transfer of tumor-infiltrating lymphocytes in patients with metastatic melanoma: Intent-to-treat analysis and efficacy after failure to prior immunotherapies. Clin Cancer Res 19(17): 47924800, 2013. PMID: 23690483 DOI: 10.1158/1078-0432.CCR13-0380

10 Takimoto R, Kamigaki T, Okada S, Matsuda E, Ibe H, Oguma E, Naitoh K, Makita K and Goto S: Efficacy of Adoptive Immune-cell therapy in patients with advanced gastric cancer: A retrospective study. Anticancer Res 37(7): 3947-3954, 2017. PMID: 28668899. DOI: 10.21873/anticanres.11778

11 Markel G, Cohen-Sinai T, Besser MJ, Oved K, Itzhaki O, Seidman R, Fridman E, Treves AJ, Keisari Y, Dotan Z, Ramon $\mathrm{J}$ and Schachter J: Preclinical evaluation of adoptive cell therapy for patients with metastatic renal cell carcinoma. Anticancer Res 29(1): 145-154, 2009. PMID: 19331144.

12 Kondo H, Hazama S, Kawaoka T, Yoshino S, Yoshida S, Tokuno $\mathrm{K}$, Takashima M, Ueno T, Hinoda and Oka M: Adoptive immunotherapy for pancreatic cancer using MUC1 peptidepulsed dendritic cells and activated T lymphocytes. Anticancer Res 28(1B): 379-387, 2008. PMID: 18383873.

13 Lu YC, Yao X, Crystal JS, Li YF, El-Gamil M, Gross C, Davis L, Dudley ME, Yang JC, Rosenberg SA and Robbins PF: Efficient identification of mutated cancer antigens recognized by $\mathrm{T}$ cells associated with durable tumor regressions. Clin Cancer Res 20(13): 3401-3410, 2014. PMID: 24987109 DOI: 10.1158/1078-0432.CCR-14-0433

14 Merhavi-Shoham E, Itzhaki O, Markel G, Schachter J and Besser MJ: Adoptive cell therapy for metastatic melanoma Cancer J 23(1): 48-53, 2017. PMID: 28114254. DOI: 10.1097/ PPO.0000000000000240

15 Dudley ME, Wunderlich JR, Yang JC, Sherry RM, Topalian SL, Restifo NP, Royal RE, Kammula U, White DE, Mavroukakis SA, Rogers LJ, Gracia GJ, Jones SA, Mangiameli DP, Pelletier MM, Gea-Banacloche J, Robinson MR, Berman DM, Filie AC, Abati A and Rosenberg SA: Adoptive cell transfer therapy following non-myeloablative but lymphodepleting chemotherapy for the treatment of patients with refractory metastatic melanoma. J Clin Oncol 23(10): 2346-2357, 2005. PMID: 15800326. DOI: $10.1200 / J C O .2005 .00 .240$

16 Klebanoff CA, Khong HT, Antony PA, Palmer DC and Restifo NP: Sinks, suppressors and antigen presenters: how lymphodepletion enhances T cell-mediated tumor immunotherapy. Trends Immunol 26(2): 111-117, 2005. PMID: 15668127. DOI: 10.1016/ j.it.2004.12.003

17 Muranski P, Boni A, Wrzesinski C, Citrin DE, Rosenberg SA, Childs R and Restifo NP: Increased intensity lymphodepletion and adoptive immunotherapy - how far can we go? Nat Clin Pract Oncol 3(12): 668-681, 2006. PMID: 17139318. DOI: $10.1038 /$ ncponc0666

18 Goff SL, Dudley ME, Citrin DE, Somerville RP, Wunderlich JR, Danforth DN, Zlott DA, Yang JC, Sherry RM, Kammula US, Klebanoff CA, Hughes MS, Restifo NP, Langhan MM, Shelton TE, Lu L, Kwong ML, Ilyas S, Klemen ND, Payabyab EC, Morton KE, Toomey MA, Steinberg SM, White DE and Rosenberg SA: Randomized prospective evaluation comparing intensity of lymphodepletion before adoptive transfer of tumorinfiltrating lymphocytes for patients with metastatic melanoma. J Clin Oncol 34(20): 2389-2397, 2016. PMID: 27217459. DOI: 10.1200/JCO.2016.66.7220

19 Andersen R, Donia M, Ellebaek E, Borch TH, Kongsted P, Iversen TZ, Hölmich LR, Hendel HW, Met Ö, Andersen MH, Thor Straten P and Svane IM: Long-lasting complete responses in patients with metastatic melanoma after adoptive cell therapy with tumor-infiltrating lymphocytes and an attenuated IL-2 regimen. Clin Cancer Res 22(15): 3734-3745, 2016. PMID: 27006492. DOI: 10.1158/1078-0432.CCR-15-1879

$20 \mathrm{Wu}$ R, Forget M-A, Chacon J, Bernatchez C, Haymaker C, Chen JQ, Hwu P and Radvanyi L. Adoptive T-cell therapy using 
autologous tumour-infiltrating lymphocytes for metastatic melanoma: Current status and future outlook. Cancer J 18(2): 160-175, 2012. PMID: 22453018. DOI: 10.1097/PPO.0b013e $31824 \mathrm{~d} 4465$

21 Baruch EN, Berg AL, Besser MJ, Schachter J and Markel G: Adoptive T-Cell Therapy: An overview of obstacles and opportunities. Cancer 123(S11): 2154-2162, 2017. PMID: 28543698. DOI: $10.1002 /$ cncr.30491

22 Ben-Avi R, Itzhaki O, Simansky D, Zippel D, Markel G, Ben Nun A, Schachter J and Besser MJ: Metastatic lung lesions as a preferred resection site for immunotherapy with tumor infiltrating lymphocytes. J Immunother 39(5): 218-222, 2016. PMID: 27163742. DOI: 10.1097/CJI.0000000000000124

23 Itzhaki O, Hovav E, Ziporen Y, Levy D, Kubi A, Zikich D, Hershkovitz L, Treves AJ, Shalmon B, Zippel D, Markel G, Shapira-Frommer R, Schachter J and Besser MJ: Establishment and large-scale expansion of minimally cultured "young" tumor infiltrating lymphocytes for adoptive transfer therapy. J Immunother 34(2): 212-220, 2011. PMID: 21304398. DOI: 10.1097/CJI.0b013e318209c94c

24 Dudley ME, Wunderlich JR, Shelton TE, Even J and Rosenberg SA: Generation of tumor-infiltrating lymphocyte cultures for use in adoptive transfer therapy for melanoma patients. J Immunother 26(4): 332-342, 2003. PMID: 12843795.

25 Besser MJ, Shapira-Frommer R, Treves AJ, Zippel D, Itzhaki O, Schallmach E, Kubi A, Shalmon B, Hardan I, Catane R, Segal E, Markel G, Apter S, Ben Nun A, Kuchuk I, Shimoni A, Nagler A and Schachter J: Minimally cultured or selected autologous tumor infiltrating lymphocytes following a lymphodepleting chemotherapy regimen in metastatic melanoma patients. J Immunother 32(4): 415-423, 2009. PMID: 19342963. DOI: 10.1097/CJI.0b013e31819c8bda

26 Schallmach E, Sareli R, Besser MJ, Leipsiger S, Hardan I, Treves AJ, Nagler A and Schachter J: Collection of large- scale expanded lymphocyte cultures for adoptive immunotherapy using a COBE spectra apheresis machine. J Immunother 31(6): 563-568, 2008. PMID: 18528298. DOI: 10.1097/CJI.0b013e31 $8175 \mathrm{f} 66 \mathrm{~b}$

27 Antony PA, Piccirillo CA, Akpinarli A, Finkelstein SE, Speiss PJ, Surman DR, Palmer DC, Chan CC, Klebanoff CA, Overwijk WW, Rosenberg SA and REstifo NP: CD8+ T cell immunity against a tumor/self-antigen is augmented by $\mathrm{CD} 4+\mathrm{T}$ helper cells and hindered by naturally occurring $\mathrm{T}$ regulatory cells. J Immunol 174(5): 2591-2601, 2005. PMID: 15728465. DOI: 10.4049/jimmunol.174.5.2591

28 Gattinoni L, Finkelstein SE, Klebanoff CA, Antony PA, Palmer DC, Spiess PJ, Hwang LN, Yu Z, Wrzesinski C, Heimann DM, Surh CD, Rosenberg SA and Restifo NP: Removal of homeostatic cytokine sinks by lymphodepletion enhances the efficacy of adoptively transferred tumor- specific CD8+T cells. J Exp Med 202(7): 907-912, 2005. PMID: 16203864. DOI: 10.1084/jem.20050732

29 Zhou J, Dudley ME, Rosenberg SA and Robbins PF. Persistence of multiple tumor-specific T-cell clones is associated with complete tumor regression in a melanoma patient receiving adoptive cell transfer therapy. J Immunother 28(1): 53-62, 2005. PMID: 15614045.

30 Kvistborg P, Shu CJ, Heemskerk B, Fankhauser M, Thrue CA, Toebes M, van Rooij N, Linnemann C, van Buuren MM, Urbanus JH, Beltman JB, Thor Straten P, Li YF, Robbins PF,
Besser MJ, Schachter J, Kenter GG, Dudley ME, Rosenberg SA, Haanen JB, Hadrup SR and Schumacher TN: TIL therapy broadens the tumour-reactive $\mathrm{CD} 8+\mathrm{T}$ cell compartment in melanoma patients. Oncoimmunology 1(4): 409-418, 2012. PMID: 22754759. DOI: 10.4161/onci.18851

31 Goff SL, Smith FO, Klapper JA, Sherry R, Wunderlich JR, Steinberg SM, White D, Rosenberg SA, Dudley ME and Yang JC: Tumor infiltrating lymphocytes (TIL) therapy for metastatic melanoma: analysis of tumors resected for TIL. J Immunother 33(8): 840-847, 2010. PMID: 20842052. DOI: 10.1097/CJI.0b $013 \mathrm{e} 3181 \mathrm{f05b} 91$

32 Tran KQ, Zhou J, Durflinger KH, Langhan MM, Shelton TE, Wunderlich JR, Robbins PF, Rosenberg SA and Dudley ME: Minimally cultured tumor-infiltrating lymphocytes display optimal characteristics for adoptive cell therapy. J Immunother 31(8): 742-751, 2008. PMID: 18779745. DOI: 10.1097/CJI.0b $013 \mathrm{e} 31818403 \mathrm{~d} 5$

33 Dudley ME, Gross CA, Langhan MM, Garcia MR, Sherry RM, Yang JC, Phan GQ, Kammula US, Hughes MS, Citrin DE, Restifo NP, Wunderlich JR, Prieto PA, Hong JJ, Langan RC, Zlott DA, Morton KE, White DE, Laurencot CM and Rosenberg SA: CD8+ enriched "young" tumor infiltrating lymphocytes can mediate regression of metastatic melanoma. Clin Cancer Res 16(24): 6122-6131, 2010. PMID: 20668005. DOI: 10.1158/ 1078-0432.CCR-10-1297

34 Crompton JG, Klemen N and Kammula US: Metastasectomy for tumor-infiltrating lymphocytes: An emerging operative indication in surgical oncology. Ann Surg Oncol 25(2): 565-572, 2018. PMID: 29188500. DOI: 10.1245/s10434-017-6266-8

35 Parry RV, Chemnitz JM, Frauwirth KA, Lanfranco AR, Braunstein I, Kobayashi SV, Linsley PS, Thompson CB and Riley J: CTLA-4 and PD-1 receptors inhibit T-cell activation by distinct mechanisms. Mol Cell Biol 25(21): 9543-9553, 2005. PMID: 16227604. DOI: 10.1128/MCB.25.21.95439553.2005

36 Rudd CE, Taylor A and Schneider H: CD28 and CTLA-4 coreceptor expression and signal transduction. Immunol Rev 229(1): 12-26, 2009. PMID: 19426212. DOI: 10.1111/j.1600065X.2009.00770.x

37 Robert C, Thomas L, Bondarenko I, O'Day S, Weber J, Garbe C, Lebbe C, Baurain JF, Testori A, Grob JJ, Davidson N, Richards J, Maio M, Hauschild A, Miller WH Jr, Gascon P, Lotem M, Harmankaya K, Ibrahim R, Francis S, Chen TT, Humphrey R, Hoos A and Wolchok JD: Ipilimumab plus dacarbazine for previously un-treated metastatic melanoma. $\mathrm{N}$ Engl J Med 364(26): 2517-2526, 2011. PMID: 21639810. DOI: 10.1056/NEJMoa1104621

38 Chambers CA, Kuhns MS, Egen JG and Allison JP: CTLA-4mediated inhibition in regulation of $\mathrm{T}$ cell responses: mechanisms and manipulation in tumor immunotherapy. Annu Rev Immunol 19: 565-594, 2001. PMID: 11244047. DOI: 10.1146/annurev.immunol.19.1.565

39 Intlekofer AM and Thompson CB. At the bench: Preclinical rationale for CTLA-4 and PD-1 blockade as cancer immunotherapy. J Leukoc Biol 94(1): 25-39, 2013. PMID: 23625198. DOI: $10.1189 /$ jlb.1212621

40 Thibult ML, Mamessier E, Gertner-Dardenne J, Pastor S, JustLandi S, Xerri L, Chetaille B and Olive D: PD-1 is a novel regulator of human B-cell activation. Int Immunol 2013; 25(2): 129-137. PMID: 23087177. DOI: 10.1093/intimm/dxs098 
41 Texeidó C, González-Cao, Karachaliou $\mathrm{N}$ and Rosell $\mathrm{R}$ : Predictive factors for immunotherapy in melanoma. Ann Trans Med 3(15): 208, 2015. PMID: 26488004. DOI: 10.3978/j.issn. 2305-5839.2015.05.07

42 Seidel JA, Otsuka A and Kabashima K: Anti-PD-1 and antiCTLA-4 therapies in cancer: mechanisms of action, efficacy and limitations. Front Oncol 8: 86, 2017. PMID: 29644214. DOI: 10.3389/fonc.2018.00086

43 Tumeh PC, Harview CL, Yearley JH, Shintaku IP, Taylor EJ, Robert L, Chmielowski B, Spasic M, Henry G, Ciobanu V, West AN, Carmona M, Kivork C, Seja E, Cherry G, Gutierrez AJ, Grogan TR, Mateus C, Tomasic G, Glaspy JA, Emerson RO, Robins H, Pierce RH, Elashoff DA, Robert C and Ribas A: PD1 blockade induces responses by inhibiting adaptive immune resistance. Nature 515(7528): 568-571, 2014. PMID: 25428505. DOI: $10.1038 /$ nature 13954

44 Schatton T, Scolyer RA, Thompson JF and Mihm MC Jr: Tumor-infiltrating lymphocytes and their significance in melanoma prognosis. Methods Mol Biol 1102: 287-324, 2014. PMID: 24258985. DOI: 10.1007/978-1-62703-727-3_16.
45 Taube JM, Anders RA, Young GD, Xu H, Sharma R, McMiller TL, Chen S, Klein AP, Pardoll DM, Topalian SL and Chen L: Colocalization of inflammatory response with B7-H1 expression in human melanocytic lesions supports an adaptive resistance mechanism of immune escape. Sci Transl Med 4(127): 127ra37, 2012. PMID: 22461641. DOI: 10.1126/scitranslmed 30003689.

46 Ji RR, Chasalow SD, Wang L, Hamid O, Schmidt H, Cogswell J, Alaparthy S, Berman D, Jure-Kunkel M, Siemers NO, Jackson JR and Shahabi V: An immune-active tumor microenvironment favours clinical response to ipilimumab. Cancer Immunol Immunother 61(7): 1019-1031, 2012. PMID: 2214689. DOI: $10.1007 / \mathrm{s} 00262-011-1172-6$
Received August 6, 2019

Revised August 16, 2019

Accepted August 17, 2019 